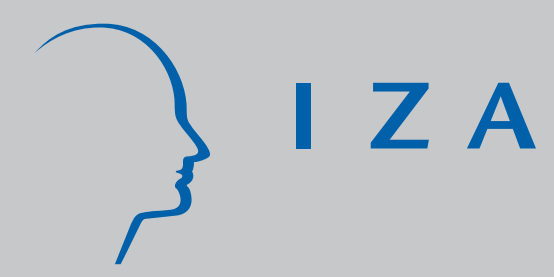

IZA DP No. 326

Privatization and Productivity in Romanian Industry: Evidence from a Comprehensive Enterprise Panel

J ohn S. Earle

Álmos Telegdy

J uly 2001 


\title{
Privatization and Productivity in Romanian Industry: Evidence from a Comprehensive Enterprise Panel
}

\author{
John S. Earle \\ SITE, Stockholm School of Economics, \\ Central European University and IZA, Bonn \\ Álmos Telegdy \\ Central European University Labor Project \\ Budapest University of Economic Sciences
}

\author{
Discussion Paper No. 326 \\ July 2001
}

\author{
IZA \\ P.O. Box 7240 \\ D-53072 Bonn \\ Germany \\ Tel.: +49-228-3894-0 \\ Fax: +49-228-3894-210 \\ Email: iza@iza.org
}

This Discussion Paper is issued within the framework of IZA's research area Labor Markets in Transition. Any opinions expressed here are those of the author(s) and not those of the institute. Research disseminated by IZA may include views on policy, but the institute itself takes no institutional policy positions.

The Institute for the Study of Labor (IZA) in Bonn is a local and virtual international research center and a place of communication between science, politics and business. IZA is an independent, nonprofit limited liability company (Gesellschaft mit beschränkter Haftung) supported by the Deutsche Post AG. The center is associated with the University of Bonn and offers a stimulating research environment through its research networks, research support, and visitors and doctoral programs. IZA engages in (i) original and internationally competitive research in all fields of labor economics, (ii) development of policy concepts, and (iii) dissemination of research results and concepts to the interested public. The current research program deals with (1) mobility and flexibility of labor markets, (2) internationalization of labor markets and European integration, (3) the welfare state and labor markets, (4) labor markets in transition, (5) the future of work, (6) project evaluation and (7) general labor economics.

IZA Discussion Papers often represent preliminary work and are circulated to encourage discussion. Citation of such a paper should account for its provisional character. 
IZA Discussion Paper No. 326

July 2001

\section{ABSTRACT}

\section{Privatization and Productivity in Romanian Industry: Evidence from a Comprehensive Enterprise Panel"}

We construct and analyze a unique database with 1992-99 information on privatization transactions and labor productivity for the entire surviving population of initially state-owned industrial corporations in Romania. The data permit us to describe the post-privatization ownership structure and to test the effect of alternative privatization policies on firm performance in a panel framework. The results of OLS, LAD, and fixed-effects estimations consistently show a positive, highly significant effect of private ownership share on the level and growth of labor productivity, the estimates ranging from 13 to 32 log points for the level, and 9 to 16 for productivity growth. The strongest estimated impacts arise from sales to foreign and domestic blockholders, but insider and mass privatization are also estimated to have positive, although smaller, impacts on firm performance.

JEL Classification: $\quad$ G32, G34, L32, L33, P20, P31

Keywords: Privatization, ownership, firm performance, restructuring, transition, Romania

John S. Earle

SITE

Stockholm School of Economics

Sveavägen 65, P.O. Box 6501

SE-11383 Stockholm

Sweden

Tel.: +46-8-736-9680

Fax: +46-70-578-7899

Email: John.Earle@hhs.se

\footnotetext{
" This paper is partly based on research supported by the World Bank. Data collection received support from the European Commission's Phare ACE Programme.
} 


\section{Introduction}

The impact of privatization on enterprise performance has been one of the key policy issues in the transformation of transitional economies, and a sizable empirical literature is accumulating on the topic. ${ }^{1}$ In this paper, we extend the privatization-performance research agenda to Romania, a large country in Eastern Europe that has benefited from relatively little systematic analysis. Previous studies of Romanian privatization have focused on description of the policies themselves and they provided neither an analysis of the resulting ownership structure nor of the effects of the various methods on firm performance, ${ }^{2}$ while previous research on firm performance in Romania has generally relied on small samples of firms and focused on issues other than privatization. ${ }^{3}$

Besides adding Romania to the list of countries for which an analysis of postprivatization ownership and enterprise performance has been conducted, our study is also motivated by the broader lessons that Romania's experience may offer on the effects of alternative privatization policies and ownership structures on firm behavior. To start with, the privatization process in Romania has been quite heterogeneous, involving all the major methods employed in transition economies: employee buyouts, mass privatization, and sales to domestic and foreign investors. The employee buyouts and mass privatization resulted in dispersed inside and outside ownership, respectively, while the sales nearly always involved large blocks of shares. At the same time, the process has been incomplete, leaving many companies fully or partially in state hands. Thus, the post-privatization ownership structure contains significant

\footnotetext{
${ }^{1}$ Djankov and Murrell (2000) and Megginson and Netter (2000) provide surveys of research on enterprise restructuring in transition economies and on privatization, respectively.

${ }^{2}$ See, for instance, Earle and Sapatoru (1994), Munteanu (1997), Earle and Telegdy (1998), and Negrescu (2000).

${ }^{3}$ An exception is Claessens et al (1997), but their data run only through 1995 and contain only a dummy for privatization (results discussed below). Other firm-level studies for Romania include Konings (1997) on the impact of competition, Konings and Repkin (1998) on the relationship of technical efficiency and profitability, Carlin et al (1999) on European Union accession, and Djankov (1999) on the "isolation" program for loss-making firms.
} 
components of insiders, outsiders, and the state, and, among firms with private outside shareholders, examples of concentrated and dispersed as well as foreign and domestic ownership.

The database available for Romania, which we have constructed from several sources, enables us to measure virtually all privatization transactions concerning the corporatized enterprises during the 1992-99 period in Romania and to draw inferences concerning these different types of acquiring owners. To compare the impact of owner-types on firm performance, we have linked the ownership information with panel data containing basic information on industrial firms over the same period. Thus, unlike previous studies of the impact of privatization in most countries, we are able to provide estimates based on a large sample, including nearly the entire surviving population of industrial joint-stock companies employees, eligible for privatization in Romania - 92.9 percent of such companies in 1999 - and containing panel data spanning the period from before privatization took place until after much of it had occurred. We employ a variety of alternative econometric techniques to control for heterogeneity, selection bias and potential measurement error, and we use both the level and growth of labor productivity as performance indicators to check the robustness of our findings. We also consider alternative specifications of the functional form through which ownership affects firm performance, in particular by examining the impact of majority privatization and of the type of the largest owner (a specification commonly adopted in the literature), and we analyze the dependence of the ownership-performance relationship on the length of time elapsed since privatization.

Section 2 describes the Romanian privatization process and post-privatization ownership structure. Section 3 presents the econometric specifications we employ, and Section 4 reports our estimation findings, including comparisons with the findings of related studies using similar 
data and techniques in other countries. Section 5 concludes, while the description of the database construction is relegated to an Appendix.

\section{Privatization Process and Ownership Outcomes}

This section sketches a brief history of the Romanian privatization process as well as our computations, based on the database we have constructed, of the post-privatization ownership structure. Our chief purpose is to analyze the corporate governance implications of the privatization policies in order to motivate hypotheses concerning their effects on postprivatization firm performance, but the results in this section also represent the first comprehensive picture of the results of privatization for industrial ownership in Romania. We begin by recounting the initial selection of state-owned enterprises (SOEs) for corporatization and eventual privatization, the set of companies that constitutes the sample analyzed in this paper. We then go on to describe the three major methods of privatization employed in Romania - management-employee buyout (MEBO), mass privatization program (MPP), and sales of blocks of shares - and the consequences of these methods for corporate governance and ownership structure.

As in other transition economies, the process of enterprise reform in Romania began with corporatization of the SOEs, in order to make possible their transfer to multiple owners. In Romania the legal conversion took place already in 1990, when the SOEs were divided into two groups: regii autonome and commercial companies. The former group, designated as "strategic," was relatively small in number (about 400 companies), although estimates suggest that the included companies were large (accounting for 47 percent of total SOE assets, according 
to Romanian Development Agency, 1997). ${ }^{4}$ Our attention in this paper is focused on the second group of companies, nearly all of which were reorganized as open joint-stock companies, with their shares subsequently conveyed to a newly established State Ownership Fund (SOF) and one of five Private Ownership Funds (POFs) in a ratio of 70:30 percent. Despite their name, the POFs remained state-governed, their boards of directors appointed by the Government subject to the approval of both houses of Parliament, and their nominal owners, approximately 18 million Romanian citizens, without any effective means of control. Thus, we treat the POFs as a separate category - neither private, nor state - in the empirical analysis. ${ }^{5}$

The Romanian Privatization Law of 1991 and associated regulations charged the SOF with the privatization of all the shares in its portfolio within seven years, although the Law provided little guidance on how this was supposed to be accomplished, specifying only a very general list of possible methods to be employed (mostly variants on sales of whole firms or of packages of shares). In practice, however, there have been three fairly specific methods dominating Romanian privatization: management-employee buyout (MEBO), the mass privatization program (MPP), and sales to single investors. The MEBO method dominated from the beginning, already receiving some encouragement in the Privatization Law's provision for preferential terms for managers and employees, which included right of first refusal and installment payments at very low interest rates. ${ }^{6}$

\footnotetext{
${ }^{4}$ Calculations from the Romanian Enterprise Registry (all registered firms with more than three employees) provide further evidence on the large size of the regii: in 1992, their average employment was 2988 (357 firms), compared to an overall Romanian average of 145 (38,833 firms).

${ }^{5}$ Earle and Sapatoru (1994) describe the legal basis for the POFs' operations. In 1996-97, the POFs were converted into investment funds (known in Romanian as "SIFs"), but we refer to them as POFs throughout this paper for simplicity. See Negrescu (2000) for further discussion.

${ }^{6}$ MEBOs began in earnest in 1993, but a law formalizing the practices was adopted only in 1994; see Munteanu (1997) for a detailed discussion. After 1996, sales to employees were no longer formally referred to as "MEBOs," but the institutional arrangements remained the same.
} 
Privatization through transfers (giveaways or sales at low prices) to employees have been common but controversial in transition economies, as this method has been relatively easy to implement from the administrative and political points-of-view, but is also frequently alleged to be ill-suited to the restructuring demands of the transition. ${ }^{7}$ On the one hand, insider privatization may improve work incentives, company loyalty, and support for restructuring, and if ownership is widely dispersed among employees it may facilitate takeovers by outsiders. On the other hand, employees may lack the necessary skills, capital, access to markets and technologies necessary to turn their firms around, and corporate governance by employees may function particularly poorly when the firm requires difficult restructuring choices involving disparate distributional impacts within the firm. ${ }^{8}$

While such standard arguments may be relevant for every form of employee ownership in the transition economies, the Romanian MEBOs have some significant institutional peculiarities stemming largely from the legal requirement, in order to obtain the payment preferences, that the employees establish an employees' association to hold the shares and exercise most ownership rights during the repayment period of 3-5 years. During this period, the unpaid shares may not be resold, limiting the possibility for concentration or takeovers that might improve governance. Moreover, the Romanian privatization contracts often included restrictions, also valid for the repayment period, on changes in the firm's employment level and main product. ${ }^{9}$ The complicated governance and limitations on restructuring that resulted from these arrangements

\footnotetext{
7 Frydman and Rapaczynski (1994), for instance, argue that insiders are unlikely to undertake necessary restructuring, while Ellerman (1993) provides a contrary view. Earle and Estrin (1996) provide an overview of the debate.

${ }^{8}$ See Hansmann (1990) for this argument in explaining the patterns of worker ownership in Western economies.

9 Anecdotal evidence suggests there has been an at least occasional practice of voting within the employee association according to one-member one-vote, rather than by shareholding. Particularly during the repayment period, the MEBO may be thought of as a hybrid organization, part corporation and part producer cooperative (for a discussion of the latter form, see Bonin et al, 1993).
} 
during the repayment period may have further attenuated any potentially positive effects of privatization on these firms' performance.

As shown in Table 1, a total of 858 industrial firms - over a third of all industrial firms in the SOF portfolio - had undergone MEBO transactions by 1998, with a mean employee stake of 64.9 percent and a median of 70.6 percent. ${ }^{10}$ Table 2 displays the evolution of ownership over 1992-98, showing that MEBOs were most common in the years 1994 and 1995, although employees continued to buy out their companies through 1998, the last year in our database. Measured as the average percentage of shares privatized, MEBO has been the single most important privatization method in Romania.

\section{Insert Tables 1 and 2 about here.}

In addition to the institutional peculiarities discussed above, therefore, insider privatization in Romania also differs from that in other transition economies in the magnitude of the insider share in the affected firms. Unlike most share transfers to employees in Hungary and Poland, and to an even greater degree than in Russia, the Romanian MEBOs tended to result in overwhelming employee ownership: usually the entire SOF stake of 70 percent, although there were also some cases of minority participation (sometimes combined together with other methods, mass privatization or a block sale, described below). ${ }^{11}$ The MEBOs therefore provide an interesting opportunity to test the effect of dominant employee ownership in transition.

A second major method was voucher privatization. As elsewhere in Eastern Europe, the rationale for this method was to increase the speed of privatization by overcoming the problems of insufficient demand due to low domestic savings and reluctance of foreign investors (e.g., Frydman and Rapaczynski, 1994). The programs, frequently labeled "mass privatization," were

\footnotetext{
${ }^{10}$ The Appendix describes the construction of our database, restricted to industrial firms for the present analysis.

${ }^{11}$ POFs often sold their shares simultaneously with the SOF, resulting in a 100 percent buyout by employees.
} 
also intended to jump-start domestic equity markets with a rapid release of shares. On the other hand, such programs run the risk of highly dispersed ownership structures, a problem normally addressed through the creation of intermediaries - either by the state as part of the program (e.g., in Poland), or by private parties competing for individuals' vouchers (e.g., in Czechoslovakia). Although there has been rather little empirical evidence on the effects of these programs, a number of authors have been highly critical of them. ${ }^{12}$

The Romanian mass privatization program (MPP), carried out in 1995-96, provides an opportunity to estimate the effects of a rather extreme form of voucher privatization: one that ensured maximal dispersion of ownership by prohibiting the trading of vouchers and the formation of intermediaries. The potential benefits of the program may also have been reduced by the large stake kept by the state: in most companies included in the program, only 60 percent of the shares were offered, while in those deemed "strategic" (which tended to be relatively large firms) the figure was only 49 percent. Even these percentages were reached in very few companies, due to the peculiar asymmetry of the treatment of excess demand and excess supply by the allocation procedure: oversubscription resulted in pro rata allocation, while undersubscription resulted in untransferred shares. ${ }^{13}$ As Table 1 shows, a total of 1727 industrial firms were included in the program, with a mean of 24.5 percent and a median of 18.4 percent privatized; only about one-sixth of the firms in the program were majority privatized.

The consequence was inevitably an ownership structure heavily dominated by the state (often retaining the majority stake) facing a highly dispersed group of private owners. Any hope for a positive impact of this program would seem to rely on an indirect mechanism: either through secondary sales leading to increased private ownership concentration, through share

\footnotetext{
${ }^{12}$ See, e.g., Stiglitz (1999), Black et al (2000), Kornai (2000), and Roland (2000).

${ }^{13}$ Earle and Telegdy (1998) report details of the MPP procedures.
} 
trading that increases information about firm performance and therefore managerial incentives, or through some complementarity with other owners, particularly blockholders that purchased shares through a direct sale. In such cases, the MPP may still have had a positive effect, despite its design.

Shares in the MPP were taken both from the SOF and the five POFs, but the latter could regain some shares if citizen-participants in the MPP exercised their option to place their vouchers with one of them. On average, however, the POFs were net losers from this procedure: as shown in Table 2, their mean share dropped from 23.8 percent at the end of 1995 to 9.2 percent a year later. Both before the MPP and subsequently, the POFs have also sold shares from their portfolios, resulting in a reduction of their stake to only 8.1 percent by the end of 1998. Frequently, such sales were organized in conjunction with SOF privatization sales.

The third major type of privatization method employed in Romania has been case-by-case sales of large blocks of shares. Although sales were intended to be the primary method from the very beginning of the process in 1991, they proceeded only slowly, being superceded by the MEBO and MPP methods before 1997. Until this year, as shown in Table 2, domestic and foreign investors accounted for only a small fraction of Romanian privatizations, on average, owning only 3.9 and 0.8 percent, respectively, by the end of 1997. Perhaps due to the abolition of minimal price requirements, or an increase in "political will," the rate of sales increased thereafter: during 1998 the average holding of domestic investors doubled (from 3.9 to 8.2 percent) and that of foreign investors' almost tripled (from 0.8 to 2.3 percent). As with the MEBO transactions, sales of blocks to outside investors frequently had contractual restrictions on post-privatization behavior, including changes in employment (Negrescu, 2000). Such restrictions may have reduced restructuring in the companies privatized through block sales, 
reducing the potential benefits of privatization. Unfortunately, our database does not permit us to measure them.

Table 3 provides an alternative picture of the privatization process based on classifying firms according to the type of largest owner. At the end of 1998, the state still remained the largest owner in almost half of the companies. After the state, insiders dominated in the largest number of firms (24.5 percent at the end of the period studied) followed by the dispersed MPP owners (14.2 percent). Outsider blockholders had a majority in only 12.6 percent of firms; most of these were domestic owners (9.3 percent), and foreign investors were dominant in only 3.3 percent of the firms.

Insert Table 3 about here.

To summarize the ownership results, by the end of 1998 the state's share in the corporatized industrial companies had fallen to 36.3 percent on average. Most of the companies with private ownership became majority private. The most prevalent types of owners were employees (23.6 percent on average) and participants of the Mass Privatization Program (18.2 percent on average). Table 1 shows, that for 1875 companies - more than three-quarters of the total - the SOF retained some ownership stake; within this group, the average state share was quite high, at 46.9 percent. Concentrated outsiders - domestic and foreign - are present in 476 (20 percent) of the companies, but again the average in this group of firms is a majority stake. The heterogeneity of the Romanian privatization methods thus produced an interesting testing ground for examining the impact of alternative ownership structures on firm performance. 


\section{Empirical Specification}

In this section we first describe our measures of firm performance, which are the dependent variables in our analysis of the effects of privatization and the new ownership structures. Second, we present the equations that we estimate. Results are reported in the following Section 4.

Our performance measures in this paper are the level and growth in the natural log of labor productivity (the ratio of real revenue to employment). To some extent, this choice is determined by data availability: while our constructed ownership database (described in the Appendix) is quite rich as regards the privatization process, we have been able to match this information with only a few basic firm variables: revenue, employment, industry, and region. Without a measure of the capital stock or other inputs, we cannot estimate total factor productivity, nor do we have measures of profits, return to assets or Tobin's Q, which have been used in Western studies of corporate governance. But we would also argue that these measures of firm performance may be less appropriate in the transition context where part of the capital stock was acquired during the socialist period of fixed and arbitrary prices, where hiding of profits is ubiquitous, and where few company stocks trade in institutionalized markets and those that do frequently have stated prices that may bear little relationship to actual value. Moreover, other studies of the impact of privatization on performance have also tended to emphasize labor productivity (e.g., Earle, 1998; Frydman et al, 1999), enabling us to compare our results with some of those in the broader literature.

Table 4 shows summary statistics for the levels of average employment, real value of sales (in thousand 1992 lei), and labor productivity. According to the data, average employment in industrial enterprises dropped every year by 8-17 percent, except for 1996, when the fall was 
around 4 percent. Over the whole period, the cumulative drop was 55.7 percent on average. The real value of sales and labor productivity displayed much more volatile patterns, rising in some years and falling in others.

Insert Table 4 about here.

Turning to the econometric specifications, we report 24 alternative sets of estimations, with the purpose of investigating the robustness of our findings. The specifications differ in the dependent variable, the regression method, and the specification of the private ownership variables. We employ two alternative dependent variables - the level and the growth of labor productivity (as described above), three estimation methods - ordinary least squares (OLS), least absolute deviations (LAD or median regression), and firm fixed-effects (FE), and four versions of ownership structure - the aggregated private share, the disaggregated shares by type of new private owner, a majority private dummy and a set of dummy variables for the largest ownertype. When the dependent variable is log of labor productivity $(L O G P R)$, the regressors are the lagged ownership variables, previous performance (lagged log labor productivity), size (lagged log employment, LOGEMP), 5 region and 13 industry dummies: ${ }^{14}$

$$
\operatorname{LOGPR}_{t, i}=\alpha_{\mathrm{t}}+\beta O W N_{t-1, i}+\gamma \operatorname{LOGPR}_{t-1, i}+\delta L O G E M P_{t-1, i}+\eta \operatorname{REGION}_{i}+\varphi \operatorname{INDUSTRY}_{i}+\varepsilon_{\mathrm{i}},
$$

where $t$ indexes years, the $\alpha_{t}$ are year effects, and $O W N_{t-1}$ alternatively represents the percent of private ownership, a vector of the percentage owned by different ownership types - employees, vouchers, domestic and foreign investors and others, the non-identifiable owners, a dummy for majority private ownership, and a vector of dummies for the largest owner-type. As described in Section 2, above, the POF holdings are also included as a separate category. These equations were estimated both by OLS and LAD.

\footnotetext{
${ }^{14}$ The regions are Bucharest, Moldova, Muntenia, Oltenia, Transilvania and Crisana-Banat. The industries are extraction and power supply, textiles, footwear, wood industry, publishing, chemistry, ceramics, metallurgy,
} 
The growth regression specifies the dependent variable as the annual logarithmic change in labor productivity:

$$
\operatorname{LOGPR}_{t, i}-\operatorname{LOGPR}_{t-1, i}=\alpha_{\mathrm{t}}+\beta O W N_{t-1, i}+\delta \operatorname{LOGEMP}_{t-1, i}+\eta \operatorname{REGION}_{i}+\varphi \operatorname{INDUSTRY}_{i}+\varepsilon_{\mathrm{i}} .
$$

The fixed-effects regressions are specified as follows:

$$
\begin{gathered}
\operatorname{LOGPR}_{t, i}=\alpha_{\mathrm{i}}+\alpha_{\mathrm{t}}+\beta O W N_{t-1, i}+\delta L O G E M P_{t-1, i}+\varepsilon_{\mathrm{i}} \\
\operatorname{LOGPR}_{t, i}-\operatorname{LOGPR}_{t-1, i}=\alpha_{\mathrm{i}}+\alpha_{\mathrm{t}}+\beta O W N_{t-1, i}+\delta L O G E M P_{t-1, i}+\varepsilon_{\mathrm{i}},
\end{gathered}
$$

where the $\alpha_{\mathrm{i}}$ are firm fixed-effects.

Finally, we analyze whether the relation between privatization and performance depends on the time that has passed since the privatization. For this purpose we follow Claessens, Djankov, and Pohl (1997), in using dummy variables for each year of lag after privatization, with the $4^{\text {th }}$ through $7^{\text {th }}$ lags aggregated, due to the very small number of observations privatized in the years 1992-95. These dummies are interacted with the majority privatization dummy.

\section{Results}

Our analysis of the Romanian privatization policies, in Section 2 above, suggested that sales to outside blockholders, resulting in concentrated outside ownership, are most likely to have raised firm efficiency. Foreign investors, in particular, seem likely to have the best incentives, expertise and financing abilities, followed by domestic blockholders (institutions and individuals). Even these investors, however, may be handicapped by contractual restrictions and other impediments to restructuring posed by Romanian policies and the business environment. We have also hypothesized that firms bought out by their employees may exhibit lower productivity performance due to the pursuit of non-value-maximizing objectives, difficulties in raising capital, and the continued role of the state, due to the institutional design of the MEBO

machine building, electrical equipment, furniture and other unclassified, and recycling. 
privatization process. Finally, the highly dispersed ownership structure resulting from the mass privatization suggests that MPP participants may be unlikely to contribute much to corporate governance, although secondary transactions might have created some concentration (that we cannot observe). The weakness of these latter two programs raises the question whether they have resulted in any improvements in firm performance relative to continued ownership by the state, or indeed, given that most Romanian privatization was either MEBO or MPP, whether on average privatization in Romania has made any difference.

Our results, presented in Tables 5-12, provide empirical evidence to evaluate these hypotheses. First, the level of privatization is estimated to have a positive and significant effect in every equation, as Tables 5 and 6 show. The magnitude of the coefficient varies between 0.131 and 0.225 in the level regressions and between .086 and .114 in the growth equations, depending on the estimation method employed. These results implies a sizable, but plausible impact of privatization, on average. The impact of POF ownership on performance is also positive and statistically significant in many of the regressions, although it tends to have a large standard error.

Insert Table 5 and 6 about here.

Similar regressions in which the private share variable is replaced by a dummy for majority private ownership, not shown in the tables, yield very similar results. The coefficient of the majority private dummy is between $0.08-0.12$ for the level of productivity, and between 0.053-0.076 for the growth equations. All coefficients are significant at the 1-percent level.

These results for the basis for the estimation results in Tables 7 and 8 concerning the relation of the time lag between privatization and its effect on the level and growth of productivity. We find that for any time-lag, privatization always has a positive effect on the 
level and growth of labor productivity. Our results show that privatization has the largest impact on the level of labor productivity after one and three years (the coefficients are in the range 0.089-0.138 and 0.098-0.145, respectively). We find similar results for the growth equations, but in these regressions the effect of the one-year privatization is clearly the highest $(0.069-0.105)$. Insert Tables 7 and 8 about here.

Next, we turn to our results from estimating the effects of disaggregated ownership categories. These are also always estimated to have positive and significant effects, as shown in Tables 9 and 10. In particular, the foreign ownership share is estimated to have a positive and relatively large impact on the performance of firms, ranging from .274 to .423 for the level and from .161 to .295 for the growth of productivity; for every regression the coefficient is highly significant. In four out of six regressions, the foreign coefficients are the largest, while in the other two domestic blockholders do slightly better.

Insert Tables 9 and 10 about here.

Both types of blockholders display distinctly better performance than do MEBO and MPP participants, but it is noteworthy that the latter two types of owners nonetheless always have positive and significant coefficients at the 1-percent level. The difference in the effects of these two types is not large, but the MPP share usually has a slightly larger coefficient.

Turning to an alternative specification of disaggregated owner-types, Tables 11 and 12 show the effect of the largest owner-type on the level and growth of log labor productivity. Among the identifiable owners, the results are quite similar to the previous findings: domestic and foreign blockholders have the largest coefficients, while those for MEBO and MPP participants are also positive although smaller. In these regressions, however, the category with 
the largest coefficients is usually "others," the unclassifiable ownership type. As Table 3 showed, only a tiny fraction of firms have an unclassified dominant owner.

\section{Insert Tables 11 and 12 about here.}

How do our results relate to the findings of other studies? First of all, it should be pointed out that there are no comparable studies for Romania, and indeed there are few for other transition economies as well. Most such studies have been undertaken with small samples of firms observed only shortly after their privatization process began. Among such studies, Earle (1998) estimates productivity equations for about 150 Russian enterprises, finding a coefficient of 0.5 on private share ownership; when types of private ownership are disaggregated, OLS regressions show a larger impact of managerial than other types of ownership, but in instrumental variable specifications concentrated outside owners have the biggest impact, consistent with the results shown here. A second study, Frydman et al's (1999) analysis of around 200 firms in Central Europe, estimates an impact on productivity growth of .043 for a dummy variable for private ownership and .164 for private domestic financial firms, although neither foreign investors nor private domestic nonfinancial firms have statistically significant effects. Their data run only through 1993, however, making it difficult to draw firm conclusions.

In a study of five transitional countries for a slightly later period (1992-1995), Claessens, Djankov and Pohl's (1997) specification permits the effect of a privatization dummy on total factor productivity to vary across years since privatization. For Romania, they find a similar positive effect to ours for three years after privatization; however, for the one-year lag their coefficient is negative. The positive effect for each time-lag is not found in Villalonga's (2000) study of 24 privatized Spanish enterprises, which suggested that firm efficiency decreases after 5-6 years, followed by an increase after 7-8 years. 
A caveat to our results, as well as most of those in the literature, is the possibility of residual selection bias: perhaps some types of owners were able to obtain shares in better firms, in ways which are unobservable to the researcher but possibly observable to the buyers. If this unobservable quality is fixed for each firm, then it should be eliminated in the fixed effects estimation. The effect may be dynamic, however, if for instance the unobservable quality relates to potential for restructuring and improvements in productivity growth, rather than being intertemporally fixed. This problem faces all studies of privatization and firm performance, of course, including studies that treat selection bias through fixed effects. In our case, there are unfortunately no instruments to be able to control for ownership endogeneity and the possibility of selection bias should be borne in mind in interpreting our findings.

\section{Conclusion}

The debates over how privatization affects firm performance, which privatization method works best, and which type of owner is the most suited for carrying out restructuring, have been long and heated. Yet there have been remarkably few studies that have analyzed the privatization-performance relationship using panel data from a large sample of firms containing information for periods both before and after privatization. Indeed, given that privatization policies are typically so prominent and controversial, we know remarkably little about their outcomes in the transition economies: there are few studies for any country of Central and Eastern Europe that provide a comprehensive description of the post-privatization ownership structure and its consequences for firm behavior.

In this paper, we have argued that Romania offers an interesting testing ground for two reasons: First, it has been possible to construct a data set containing high quality and nearly 
complete information on the privatization process for corporatized industrial enterprises. Second, variants of all of the major types of privatization policies are represented, resulting in an ownership structure with significant stakes held by employees, dispersed outsiders, domestic blockholders, foreign blockholders and the state.

Despite a number of corporate governance problems resulting from some peculiarities of the Romanian privatization policy design, which we have analyzed, our empirical findings provide substantial evidence that privatization has had a positive and substantial effect on the level and growth of labor productivity. As we have shown, the statistical significance of these effects remain robust across all specifications, although the point estimates do fluctuate depending on the estimation method employed. Our work also strongly supports the proposition that outsider blockholders are the most effective owners, and that among them, foreigners have the largest positive impact on the firms; again, these results are highly robust to changes in performance measure and estimation method.

More surprisingly, the estimated regression coefficients on disaggregated outsider owners (MPP participants) and on insiders (MEBO participants) are also positive, although distinctly smaller and somewhat less robustly statistically significant than the effects of outside blockholders. Thus the data provide some evidence that even these owners have a positive impact, relative to continued state ownership.

Why we find that the MEBO and MPP privatizations may have yielded improved performance is a subject on which our data permits us only to speculate, but we shall do so nevertheless. First, we should recall that our ownership measures pertain only to the privatization transactions, and we do not observe subsequent secondary sales of shares. Perhaps the employees and other individuals acquiring small quantities of shares through these programs 
were quick to sell them, and possibly some concentrated owners - outsiders or managers - have emerged and begun restructuring, although we are unable to observe this process. Second, share prices on secondary sales, particularly in an organized exchange - either the Bucharest Stock Exchange or the over-the-counter RASDAQ could possibly provide additional information to outside blockholders on firm performance, suggesting some complementarity between outside blockholder ownership with dispersed investor trading. Third, perhaps the individuals acquiring shares through the MPP were in fact employees, adding to the concentration of ownership in relatively few hands. Fourth, there may be selection bias such that firms with better potential were included in the MEBOs and MPP, as discussed in Section 4 above. Finally, the data may contain measurement error in either labor productivity or (less likely) in the ownership structure variables, creating a spurious correlation. Such measurement error would have to be biased such that MEBO and MPP firms have upward-biased productivity measures, as uncorrelated measurement error would produce simply larger standard errors (for measurement error in productivity) or downward bias in the coefficients (for measurement error in ownership).

In closing, the results appear to us strong enough to conclude that privatization has been surprisingly successful in Romania - for the firms which have in fact been privatized. For those that have not, our results suggest that waiting has been deleterious. Given the large state shareholdings that remain, this suggests that a further "acceleration" of the privatization process is in order. 


\section{Appendix: Construction of the Database}

\section{A1. Construction of Ownership Time Series}

Our analysis is based on unpublished data from multiple sources that we have linked together. The information on the ownership of the initially state-owned joint-stock companies is compiled from seven databases: the SOF (State Ownership Fund) Transactions Database, the SOF Portfolio Database, ${ }^{15}$ and one database for each of the five POFs. Table 13 lists the databases, the types of the company they have information on, and the relevant variables for our analysis.

\section{Insert Table 13 about here.}

From these sources, we were able to construct a nearly complete evolution of the ownership of all initially state-owned enterprises (except companies excluded from the SOF portfolio, most notably the regii autonome, which were not originally slated for privatization). Incomplete information in these files, however, forced us to make a number of assumptions, especially about the date of privatization and about holdings of the POFs, as we discuss below. We should also point out that the SOF has been responsible for privatizing the shares only of joint-stock ("commercial") companies, thus excluding spin-offs of shops or assets from the parent companies. In this section we report the construction of ownership time-series, our imputations when information was incomplete, and cleaning procedures.

Our starting-point in developing the ownership time-series is a data set from the SOF that we call the "Transactions Database." For all share sale transactions carried out by the SOF, this file contains the date, percentage transferred and type of buyer. Four types of buyers can be distinguished in these data: employee association, domestic individuals, domestic institutions, and foreigners. The employee association is the legal group of employees acquiring shares in a MEBO transaction, while the other three types can be assumed to be non-employee outsiders. ${ }^{16}$

This database does not contain, however, companies that had no sales transaction at all. Among such companies are those still 100 percent state-owned, and those privatized only through the Mass Privatization Program. We added these companies from a second SOF source: the "Portfolio Database." This database does not report information on the date of transaction, but this did not present any difficulty in the case of MPP privatization, because all the MPP transfers took place in 1996. The database has additional information on shares transferred directly to managers and "others," which we describe below. After matching the companies with sales transactions with the totally state-owned and the MPP firms, we obtained 8,988 companies, the total number of initially state-owned companies.

The Transactions Database also does not provide information on the status of shares initially transferred to the POFs, 30 percent in each converted joint-stock company. Although they have been putatively private since their formation in 1991, we believe it is important to distinguish the POFs from other types of owners, thus the next step in the construction of the time series was to estimate the sales of shares by these organizations. A first step relied on a variable from the portfolio database: the percentage of shares sold by the POFs from 1992 to

\footnotetext{
${ }^{15}$ Together, they provide information on the ownership structure of over 8,900 companies, all initially state-owned firms which were in the SOF's portfolio. (Regii autonome are not included, because they belonged to the branch ministry and later a number of them were transferred to the local authorities, but the SOF never had them in its portfolio).

${ }^{16}$ The data do not allow further disaggregation; for instance, different types of domestic institutions are not distinguishable.
} 
1996, before these organizations were transformed into SIFs, as we discuss in section $2 .{ }^{17}$ The number of companies where the POF is reported to have sales is relatively small, 1633 . We cleaned the variable first, because there were companies in which the POF is reported to have sold more than 30 percent, which is impossible according to the Romanian privatization laws. If the POF sale was above 35 percent (14 cases), we set the POF sale to zero, while if it was between $30-35$ percent (11 cases), we set it to 30 percent, the maximum amount the POF could have owned.

Because the data did not include the transaction date of POF sales, nor the type of buyer, we had to make several assumptions in order to include them in the time-series. First, we assumed that the POF always sold at the same time and to the same buyer as the SOF. Thus, if there were any sales reported in the SOF database between 1992-1996, the POF sales were included there. If the SOF privatized shares of a company on more than one date, or to multiple buyers, the percentage of the shares the POF sold was split among the SOF sales, weighted by the shares transferred by the SOF in each sale. For the majority of firms with POF sales during 1992-96, the SOF also privatized: 87 percent of the firms where the POF did some privatization had also SOF sales. For the firms that did not have SOF sales (212 firms), we distributed the POF sales evenly among the years 1993-1996, and assumed it was bought up by "others," an ownership category where we included all transactions for which the type of buyer was neither reported nor possible to impute. ${ }^{18}$ By this procedure, we computed the POF's ownership for the end 1992-1996 by subtracting the total yearly privatization from 30, the percentage of the shares that the POF received initially.

We also estimated the ownership time-series for the SIF holdings (Financial Investment Funds, the organizations into which the POFs were transformed after 1996). ${ }^{19}$ We took this information from five portfolio databases (one for each POF). These data were available only for the end of 1998, except in the case of POF Moldova, for which it was provided also for the end of 1997. ${ }^{20}$ We combined these information with the POF holdings in 1996, which we already used for the construction of the POF time series before 1996.

We computed the POF holdings in the following way: for the POF holdings in 1996 we used the POF information, and for the few cases when this variable was missing $(0.3$ percent of total), we made the 1996 POF holding equal with the POF holding which was the closest in time (1997 for POF Moldova, 1998 for the others). For the four POFs which did not have information for 1997, we imputed it by comparing the holdings in 1996 with those in 1998. If there was no difference between them, the case for 83.0 percent of the companies, we computed the 1997 POF holding as being equal to these holdings. If there was a difference, we computed the POF holding for 1997 as the average of 1996 and 1998 holdings, and we added the difference to the "others" category, where we included all transactions where we did not know the type of owner.

The Portfolio Database contains two more variables representing two types of transactions: managerial shares and "others," as mentioned above. The managerial shares resulted from the Law on the Management Contract (66/93), issued in the second part of 1993, and concern only 400 companies with a mean of only 0.5 percent in this subset. In the absence

\footnotetext{
${ }^{17}$ Not only is this information on the POF privatization rather incomplete, but the variable itself is incomplete, according to a SOF official.

${ }^{18}$ We did not distribute the POF sales over 1992, because in this year privatization hardly began: except of pilot privatizations (21 firms) and one other took place.

${ }^{19}$ For simplicity, we continue to call them POFs.

${ }^{20}$ Out of the 2825 firms that existed in the POF portfolio data, 179 were not in the SOF database. These may be acquisitions of the POFs other than state-owned companies. We did not add these companies to the time-series.
} 
of further information, we therefore distributed these shares evenly over the years 1994-1998, and summed it with the employee association shares to the insiders' share. The "others" variable is positive for 227 companies with a mean of 25.6 percent. According to a SOF official, this variable probably indicates capital increases after privatization, but there is no information on which type of owner acquired these shares. Thus, we cumulated them together with the several types of unknown owners to create a miscellaneous and unknown category, distributing them evenly over 1993-1998.

Due to internal inconsistencies, for a number of cases the sum of the total privatization and the POF holdings by end 1998 exceeded 100 percent. If it was more than 110, we dropped the case (222 companies). If it was between 100-110, we rescaled it to 100 . The residual category is state ownership.

\section{A2. Construction of the Performance Variable and Final Sample}

We drew the basic firm variables (activity code, number of employees and real value of sales $^{21}$ ) from the 1992-1999 Romanian Enterprise Registries, which is supposed to contain all registered firms. We built up our database from eight different files, one for each year. Our version of these data are restricted to firms with a minimum of five employees. After adding employment and sales figures to the ownership information, we constructed our final sample by selecting all industrial firms (2354 cases).

Table 14 shows the resulting database, combining the ownership and registry information. The "percentage of firms" refers to the firms with non-missing performance data as a percentage of those with ownership information. Missing values are not a large problem in these data. Table 15 shows the distribution of firms by industrial branch: the largest categories are food industry (21.5 percent), textiles and clothing (14.4 percent) and machine building and transportation equipment (12.9 percent).

Insert Table 14-15 about here.

\footnotetext{
${ }^{21}$ We deflated sales by 4-digit level PPIs, where these were available: out of a total of 367 industrial 4-digit activity codes, 75 are missing for 1993-98. The number of missing PPIs for 1999 is 91 . These were replaced by 2digit CAEN codes. For two types of activities the PPIs were not computed: calculator production (since 1997), and recycling (for all years). In these two cases we used the industry-level PPI.
} 


\section{References}

Black, Bernard, Reiner Kraakman, and Anna Tarrassova (2000), "Russian Privatization and Corporate Governance: What Went Wrong?" Stanford Law Review, Vol. 52.

Bonin, John P., Derek C. Jones, and Louis Putterman (1993), "Theoretical and Empirical Studies of Producer Cooperatives: Will Ever the Twain Meet?" Journal of Economic Literature, vol 31, pp. 1290-1320.

Carlin, Wendy, Saul Estrin, and Mark Schaffer (1999), "Measuring Progress in Transition and Towards EU Accession. A Comparison of Manufacturing Firms in Poland, Romania and Spain." CERT Discussion Paper No. 99/22, January.

Claessens, Stijn, Simeon Djankov, and Gerhard Pohl (1997), "Determinants of Performance of Manufacturing Firms in Seven European Transition Economies." Davidson Institute Working Paper No. 74, February.

Djankov, Simeon (1999), "The Enterprise Isolation Program in Romania." Journal of Comparative Economics, Vol. 27, pp. 281-293.

Djankov, Simeon, and Peter Murrell (2000), "Enterprise Restructuring in Transition: A Quantitative Survey." Draft of April 17.

Earle, John S., (1998), "Post-Privatization Ownership Structure and Productivity in Russian Industrial Enterprises," SITE Working Paper, Stockholm.

Earle, John S., and Saul Estrin (1996), "Worker Ownership in Transition." In Roman Frydman, Cheryl W. Gray, and Andrzej Rapaczynski (editors), Corporate Governance in Central Europe and Russia. Insiders and the State, Budapest: World Bank and CEU Press.

Earle, John S., and Saul Estrin (1997), "After Voucher Privatization: The Structure of Corproate Ownership in Russian Manufacturing Industry." CEPR Discussion Paper No. 1736, December.

Earle John S., and Dana Sapatoru (1994), "Incentive Contracts, Corporate Governance, and Privatization Funds in Romania." Atlantic Economic Journal, Vol 22(2), 61-79.

Earle, John S., and Álmos Telegdy (1998), "The Results of 'Mass Privatization' in Romania: A First Empirical Study." Economics of Transition, Vol. 6(2), 313-32.

Ellerman, David (1993), "Management and Employee Buy-Outs in Central and Eastern Europe: Introduction." In David Ellerman, editor, Management and Employee Buy-Outs as a Technique of Privatization, Central and Eastern European Privatization Network.

Frydman, Roman, Cheryl W. Gray, Marek Hessel, and Andrzej Rapaczynski (1999), "When Does Privatization Work? The Impact of Private Ownership on Corporate Performance in the Transition Economies," Quarterly Journal of Economics, Vol. CXIV(4), 1153-92.

Frydman, Roman and Andzrej Rapaczynski (1994), Privatization in Eastern Europe: is the State Witherning Away? Central European University Press, Budapest.

Hansmann, Henry (1990), "When Does Worker Ownership Work? ESOPs, Law Firms, Codetermination, and Economic Democracy," Yale Law Journal, Vol. 99, 1749-1816.

Konings, Jozef (1997), "Competition and Firm Performance in Transition Economies: Evidence from Firm Level Surveys in Slovenia, Hungary and Romania." CEPR Discussion Paper No. 1770, December.

Konings, Jozef and Alexander Repkin (1998), "How Efficient are Firms in Transition Countries? Firm-Level Evidence from Bulgaria and Romania," CEPR Discussion Paper No. 1839. 
Kornai, Janos (2000), "Ten Years after The Road to a Free Economy': The Author's SelfEvaluation." Paper for the World Bank Annual Conference on Development Economics, Washington DC.

Megginson, William L., and Jeffry M. Netter (2000), "From State to Market: a Survey of Empirical Studies on Privatization." Draft paper.

Munteanu, Costea (1997), "Employee Share-Ownership in Romania: The Main Path to Privatization." In Milica Uvalic and Vaugham, Eds., Privatization Surprises in Transition Economies: Employee-Ownership in Central and Eastern Europe, Cheltenham, U.K., and Lyme, N.H.: Elgar.

Negrescu, Dragos (2000), "A Decade of Privatization in Romania." In Christof Ruhl and Daniel Daianu, Eds., The Economic Transition in Romania: Past, Present, and Future, Bucharest: World Bank and Romanian Center for Economic Policies.

Romanian Development Agency (1997), Romania Yes - An Investment Guide.

Roland, Gerard (2000), "Corporate Governance and Transition Economies: Lessons from Transition." Paper presented at the World Bank Annual Conference on Development Economics, Washington DC.

Stiglitz, Joseph (1999), "Wither Reform? Ten Years of the Transition." Paper presented at the World Bank Annual Conference on Development Economics, Washington DC.

Villalonga, Belén (2000), "Privatization and Efficiency: Differentiating Ownership Effects from Political, Organizational, and Dynamic Effects." Journal of Economic Behavior and Organization, Vol. 42, pp. 43-74. 


\section{Tables}

Table 1. Post-Privatization Ownership Structure, End-1998 (conditional on a non-zero ownership share in the firm)

\begin{tabular}{lcccc}
\hline \multicolumn{1}{c}{ Type of Owner } & $\begin{array}{c}\text { Mean } \\
\text { ownership } \\
\text { (percent) }\end{array}$ & $\begin{array}{c}\text { Median } \\
\text { ownership } \\
\text { (percent) }\end{array}$ & $\begin{array}{c}\text { Number } \\
\text { of firms }\end{array}$ & $\begin{array}{c}\text { Number of firms } \\
\text { with majority } \\
\text { ownership }\end{array}$ \\
\hline MEBO participants* & 64.9 & 70.6 & 858 & 519 \\
MPP participants** & 24.5 & 18.4 & 1747 & 296 \\
Domestic blockholders & 52.7 & 42.3 & 378 & 173 \\
Foreigners & 56.6 & 51.0 & 98 & 72 \\
Others*** & 10.4 & 1.2 & 693 & 18 \\
State & 46.9 & 50.9 & 1822 & 935 \\
POF & 20.1 & 18.6 & 941 & 32 \\
\hline
\end{tabular}

Total number of firms: 2354

*Employees who obtained shares through Management-Employee Buyouts

**Individuals who obtained shares within the Mass Privatization Program

*** Owners not classifiable with available information

Table 2. Evolution of the Ownership Structure: Average Percent at Year-End

\begin{tabular}{lrrrrrrr}
\hline Type of Owner & 1992 & 1993 & 1994 & 1995 & 1996 & 1997 & 1998 \\
\hline MEBO participants* & 0.2 & 3.0 & 9.6 & 17.5 & 21.3 & 22.1 & 23.6 \\
MPP participants** & 0.0 & 0.0 & 0.0 & 0.0 & 18.2 & 18.2 & 18.2 \\
Domestic Blockholders & 0.0 & 0.0 & 0.4 & 0.6 & 2.3 & 4.1 & 8.5 \\
Foreign & 0.1 & 0.1 & 0.2 & 0.2 & 0.3 & 0.9 & 2.4 \\
Others*** & 0.0 & 0.4 & 0.8 & 1.2 & 1.3 & 2.1 & 3.1 \\
\hline Total private & $\mathbf{0 . 4}$ & $\mathbf{3 . 6}$ & $\mathbf{1 1 . 0}$ & $\mathbf{1 9 . 6}$ & $\mathbf{4 3 . 4}$ & $\mathbf{4 7 . 3}$ & $\mathbf{5 5 . 7}$ \\
POF & 29.8 & 28.7 & 26.4 & 23.9 & 9.1 & 8.7 & 8.0 \\
State & 69.7 & 67.7 & 62.6 & 56.5 & 47.5 & 44.0 & 36.3 \\
N.B. Percentage of firms & 0.4 & 3.3 & 10.3 & 18.4 & 38.7 & 43.8 & 53.8 \\
majority private**** & & & & & & & \\
\hline
\end{tabular}

Number of firms: 2354

*Employees who obtained shares through Management-Employee Buyouts

**Individuals who obtained shares within the Mass Privatization Program

***Owners not classifiable with available information

****Percentage of firms with more than 50 percent of shares privately owned 
Table 3. Largest Owner-Type: Percent of Firms at the End of Year

\begin{tabular}{lccrrrrr}
\hline Type of Owner & 1992 & 1993 & 1994 & 1995 & 1996 & 1997 & 1998 \\
\hline MEBO participants* & 0.2 & 3.0 & 9.7 & 17.4 & 21.5 & 22.3 & 24.5 \\
MPP participants** & 0.0 & 0.0 & 0.0 & 0.0 & 13.5 & 14.0 & 14.2 \\
Domestic Blockholders & 0.1 & 0.1 & 0.5 & 0.8 & 2.1 & 3.9 & 9.3 \\
Foreign & 0.1 & 0.1 & 0.1 & 0.3 & 0.3 & 1.2 & 3.3 \\
Others*** & 0.0 & 0.0 & 0.0 & 0.0 & 0.2 & 0.5 & 1.0 \\
POF & 0.0 & 0.0 & 0.0 & 0.0 & 0.1 & 0.2 & 0.2 \\
State & 99.6 & 96.7 & 89.7 & 81.6 & 62.3 & 58.0 & 47.6 \\
\hline Total & 100.0 & 100.0 & 100.0 & 100.0 & 100.0 & 100.0 & 100.0 \\
\hline
\end{tabular}

Number of firms: 2354

*Employees who obtained shares through Management-Employee Buyouts

**Individuals who obtained shares within the Mass Privatization Program

*** Owners not classifiable with available information

Table 4. Summary Statistics for Employment, Real Sales and Labor Productivity

\begin{tabular}{lccccccccc}
\hline & & 1992 & 1993 & 1994 & 1995 & 1996 & 1997 & 1998 & 1999 \\
\hline $\begin{array}{l}\text { Level of } \\
\text { employment }\end{array}$ & Mean & 1154.3 & 1009.5 & 901.8 & 812.9 & 783.6 & 723.3 & 614.0 & 512.2 \\
& Std. Dev. & 1778.0 & 1664.2 & 1598.6 & 1535.8 & 1524.3 & 1437.1 & 1250.3 & 1079.3 \\
\hline $\begin{array}{l}\text { Real value of } \\
\text { sales* }\end{array}$ & Mean & 2072.1 & 2225.1 & 1835.6 & 1898.2 & 1881.1 & 1714.7 & 1449.7 & 1250.9 \\
& Std. Dev. & 5188.2 & 7664.0 & 7867.9 & 8923.4 & 8360.7 & 9021.6 & 8288.2 & 6274.1 \\
\hline $\begin{array}{l}\text { Labor } \\
\text { productivity** }\end{array}$ & Mean & 2.07 & 2.08 & 1.67 & 1.84 & 1.88 & 1.71 & 1.70 & 1.86 \\
& Std. Dev. & 2.87 & 2.70 & 2.35 & 2.44 & 2.38 & 2.30 & 2.66 & 2.49 \\
\hline Number of firms & & 1931 & 2074 & 2115 & 2134 & 2179 & 2138 & 2202 & 2168 \\
\hline
\end{tabular}

*Thousands of 1992 lei

**Real value of sales divided by employment 
Table 5: Impact of Privatization on the Level of Productivity

\begin{tabular}{|c|c|c|c|c|c|c|}
\hline & \multicolumn{6}{|c|}{ Dependent variable: Log Labor Productivity } \\
\hline & \multicolumn{2}{|c|}{ OLS } & \multicolumn{2}{|c|}{ Median } & \multicolumn{2}{|c|}{ Fixed effects } \\
\hline & Coeff. & $\begin{array}{l}\text { Std. } \\
\text { Error }\end{array}$ & Coeff. & $\begin{array}{l}\text { Std. } \\
\text { Error }\end{array}$ & Coeff. & $\begin{array}{l}\text { Std. } \\
\text { Error }\end{array}$ \\
\hline Private share & $0.185^{* *}$ & 0.017 & $0.131 * *$ & 0.011 & $0.225 * *$ & 0.018 \\
\hline POF share & $0.183 * *$ & 0.040 & $0.119 * *$ & 0.030 & $0.297 * *$ & 0.046 \\
\hline Lagged productivity & $0.823 * *$ & 0.009 & $0.898 * *$ & 0.004 & $0.402 * *$ & 0.008 \\
\hline Lagged employment & $0.047 * *$ & 0.004 & $0.027 * *$ & 0.002 & $0.107 * *$ & 0.011 \\
\hline 1994 & $-0.281 * *$ & 0.015 & $-0.286^{* *}$ & 0.011 & $-0.241 * *$ & 0.013 \\
\hline 1995 & -0.007 & 0.015 & -0.018 & 0.011 & $-0.052 * *$ & 0.013 \\
\hline 1996 & $-0.074 * *$ & 0.014 & $-0.094 * *$ & 0.011 & $-0.075 * *$ & 0.014 \\
\hline 1997 & $-0.222 * *$ & 0.016 & $-0.208 * *$ & 0.012 & $-0.199 * *$ & 0.016 \\
\hline 1998 & $-0.204 * *$ & 0.016 & $-0.210 * *$ & 0.012 & $-0.230 * *$ & 0.017 \\
\hline 1999 & $-0.095 * *$ & 0.018 & $-0.075^{* *}$ & 0.012 & $-0.144 * *$ & 0.019 \\
\hline $\mathrm{R}^{2}$ & \multicolumn{2}{|c|}{0.733} & \multicolumn{2}{|c|}{0.553} & \multicolumn{2}{|c|}{0.215} \\
\hline \multicolumn{7}{|c|}{$\begin{array}{l}\text { Notes: } \\
\text { Number of observations: } 14,532 . \\
R^{2}: \text { adjusted R-sq for OLS, pseudo R-sq for median regression, R-sq within for fixed effects regressions. } \\
\text { Ownership variables: One year lagged values. Robust standard errors for OLS. } \\
\text { OLS and median regressions include controls for region ( } 6 \text { categories) and industry (14 categories). } \\
* *=\text { significant at } 1 \text { percent level } \\
*=\text { significant at } 5 \text { percent level }\end{array}$} \\
\hline
\end{tabular}

Table 6: Impact of Privatization on Productivity Growth

\begin{tabular}{|c|c|c|c|c|c|c|}
\hline & \multicolumn{6}{|c|}{ Dependent variable: Yearly Change in Log Labor Productivity } \\
\hline & \multicolumn{2}{|c|}{ OLS } & \multicolumn{2}{|c|}{ Median } & \multicolumn{2}{|c|}{ Fixed effects } \\
\hline & Coeff. & $\begin{array}{l}\text { Std. } \\
\text { Error }\end{array}$ & Coeff. & $\begin{array}{l}\text { Std. } \\
\text { Error }\end{array}$ & Coeff. & $\begin{array}{l}\text { Std. } \\
\text { Error }\end{array}$ \\
\hline Private share & $0.105 * *$ & 0.018 & $0.086 * *$ & 0.011 & $0.114 * *$ & 0.021 \\
\hline POF share & $0.105 * *$ & 0.041 & $0.081 * *$ & 0.030 & 0.050 & 0.055 \\
\hline Lagged employment & $0.022 * *$ & 0.004 & $0.012 * *$ & 0.002 & $0.168 * *$ & 0.013 \\
\hline 1994 & $-0.300 * *$ & 0.016 & $-0.290 * *$ & 0.011 & $-0.288 * *$ & 0.015 \\
\hline 1995 & 0.012 & 0.016 & -0.004 & 0.011 & $0.044 * *$ & 0.016 \\
\hline 1996 & $-0.069 * *$ & 0.015 & $-0.095 * *$ & 0.011 & -0.027 & 0.017 \\
\hline 1997 & $-0.215^{* *}$ & 0.016 & $-0.201 * *$ & 0.012 & $-0.177 * *$ & 0.020 \\
\hline 1998 & $-0.179 * *$ & 0.017 & $-0.189 * *$ & 0.012 & $-0.136 * *$ & 0.020 \\
\hline 1999 & $-0.058 * *$ & 0.019 & $-0.049 * *$ & 0.013 & 0.001 & 0.022 \\
\hline $\mathrm{R}^{2}$ & \multicolumn{2}{|c|}{0.078} & \multicolumn{2}{|c|}{0.059} & \multicolumn{2}{|c|}{0.076} \\
\hline
\end{tabular}

Notes:

Number of observations: 14,532 .

$R^{2}$ : adjusted R-sq for OLS, pseudo R-sq for median regression, R-sq within for fixed effects regression. Ownership variables: One year lagged values. Robust standard errors for OLS.

OLS and median regressions include controls for region (6 categories) and industry (14 categories).

** = significant at 1 percent level

$*$ significant at 5 percent level 
Table 7: Effect of Majority Privatization over Time on the Level of Productivity

\begin{tabular}{|c|c|c|c|c|c|c|}
\hline \multirow{3}{*}{$\begin{array}{l}\text { Number of years } \\
\text { since privatization }\end{array}$} & \multicolumn{6}{|c|}{ Dependent variable: Log Labor Productivity } \\
\hline & \multicolumn{2}{|c|}{ OLS } & \multicolumn{2}{|c|}{ Median } & \multicolumn{2}{|c|}{ Fixed effects } \\
\hline & Coeff. & $\begin{array}{l}\text { Std. } \\
\text { Error }\end{array}$ & Coeff. & $\begin{array}{l}\text { Std. } \\
\text { Error }\end{array}$ & Coeff. & $\begin{array}{l}\text { Std. } \\
\text { Error }\end{array}$ \\
\hline Year 0 & $0.061 * *$ & 0.013 & $0.043 * *$ & 0.011 & $0.041 * *$ & 0.014 \\
\hline Year 1 & $0.138 * *$ & 0.016 & $0.089 * *$ & 0.012 & $0.124 * *$ & 0.016 \\
\hline Year 2 & $0.093 * *$ & 0.016 & $0.077 * *$ & 0.013 & $0.119 * *$ & 0.018 \\
\hline Year 3 & $0.130 * *$ & 0.023 & $0.098 * *$ & 0.018 & $0.145 * *$ & 0.025 \\
\hline Year 4-7 & $0.087 * *$ & 0.029 & $0.058 * *$ & 0.021 & $0.097 * *$ & 0.031 \\
\hline $\mathrm{R}^{2}$ & \multicolumn{2}{|c|}{0.746} & \multicolumn{2}{|c|}{0.558} & \multicolumn{2}{|c|}{0.200} \\
\hline
\end{tabular}

Notes:

Number of observations: 12,393 .

$R^{2}$ : adjusted R-sq for OLS, pseudo R-sq for median regression, R-sq within for fixed effects regressions. Robust standard errors for OLS.

All regressions include controls for previous performance, employment size and year effects. OLS and median regressions also include controls for region (6 categories) and industry (14 categories). $* *=$ significant at 1 percent level

* = significant at 5 percent level

Table 8: Effect of Majority Privatization over Time on Productivity Growth

\begin{tabular}{|c|c|c|c|c|c|c|}
\hline & \multicolumn{6}{|c|}{ Dependent variable: Change in Log Labor Productivity } \\
\hline \multirow{2}{*}{$\begin{array}{l}\text { Number of years } \\
\text { since privatization }\end{array}$} & \multicolumn{2}{|c|}{ OLS } & \multicolumn{2}{|c|}{ Median } & \multicolumn{2}{|c|}{ Fixed effects } \\
\hline & Coeff. & $\begin{array}{l}\text { Std. } \\
\text { Error }\end{array}$ & Coeff. & $\begin{array}{l}\text { Std. } \\
\text { Error }\end{array}$ & Coeff. & $\begin{array}{l}\text { Std. } \\
\text { Error }\end{array}$ \\
\hline Year 0 & $0.035 * *$ & 0.013 & $0.034 * *$ & 0.012 & 0.026 & 0.017 \\
\hline Year 1 & $0.105 * *$ & 0.016 & $0.069 * *$ & 0.013 & $0.101 * *$ & 0.020 \\
\hline Year 2 & $0.042 * *$ & 0.016 & $0.058 * *$ & 0.014 & $0.044 *$ & 0.023 \\
\hline Year 3 & $0.055^{* *}$ & 0.022 & $0.047 * *$ & 0.020 & 0.051 & 0.031 \\
\hline Year 4-7 & -0.005 & 0.022 & -0.007 & 0.023 & 0.003 & 0.039 \\
\hline $\mathrm{R}^{2}$ & \multicolumn{2}{|c|}{0.091} & \multicolumn{2}{|c|}{0.064} & \multicolumn{2}{|c|}{0.077} \\
\hline
\end{tabular}

Notes:

Number of observations: 12,393 .

$R^{2}$ : adjusted R-sq for OLS, pseudo R-sq for median regression, R-sq within for fixed effects regressions. Robust standard errors for OLS.

All regressions include controls for previous performance, employment size and year effects. OLS and median regressions also include controls for region (6 categories) and industry (14 categories). $* *$ significant at 1 percent level

$*$ significant at 5 percent level 
Table 9: Impact of Types of Owners on the Level of Productivity

\begin{tabular}{lcccccc}
\hline & \multicolumn{3}{c}{ Dependent variable: Log Labor Productivity } \\
OLS & \multicolumn{2}{c}{ Median } & Fixed effects \\
Ownership & Coeff. & Std. & Coeff. & Std. & Coeff. & Std. \\
shares: & & Error & & Error & & Error \\
\hline Foreign & $0.423^{* *}$ & 0.101 & $0.274^{* *}$ & 0.046 & $0.352^{* *}$ & 0.072 \\
Domestic & $0.319^{* *}$ & 0.048 & $0.275^{* *}$ & 0.027 & $0.403^{* *}$ & 0.040 \\
MEBO Partics. & $0.161^{* *}$ & 0.017 & $0.114^{* *}$ & 0.011 & $0.178^{* *}$ & 0.021 \\
MPP Partics. & $0.174^{* *}$ & 0.034 & $0.107^{* *}$ & 0.023 & $0.190^{* *}$ & 0.036 \\
POF & $0.167 * *$ & 0.040 & $0.114^{* *}$ & 0.030 & $0.264^{* *}$ & 0.047 \\
Others & $0.263^{* *}$ & 0.074 & $0.179^{* *}$ & 0.053 & $0.300^{* *}$ & 0.106 \\
\hline $\mathrm{R}^{2}$ & 0.734 & \multicolumn{6}{c}{0.553} & 0.218 \\
\hline
\end{tabular}

Notes:

Number of observations: 14,532 .

$R^{2}$ : adjusted R-sq for OLS, pseudo R-sq for median regression, R-sq within for fixed effects regressions. Ownership variables: One year lagged values. Robust standard errors for OLS.

All regressions include controls for previous performance, employment size and year effects. OLS and median regressions also include controls for region ( 6 categories) and industry (14 categories).

$* *$ = significant at 1 percent level

$*$ = significant at 5 percent level

Table 10: Impact of Types of Owners on Productivity Growth

\begin{tabular}{|c|c|c|c|c|c|c|}
\hline \multirow[b]{3}{*}{$\begin{array}{l}\text { Ownership } \\
\text { shares: }\end{array}$} & \multicolumn{6}{|c|}{ Dependent variable: Change in Log Labor Productivity } \\
\hline & \multicolumn{2}{|c|}{ OLS } & \multicolumn{2}{|c|}{ Median } & \multicolumn{2}{|c|}{ Fixed effects } \\
\hline & Coeff. & $\begin{array}{l}\text { Std. } \\
\text { Error }\end{array}$ & Coeff. & $\begin{array}{l}\text { Std. } \\
\text { Error }\end{array}$ & Coeff. & $\begin{array}{l}\text { Std. } \\
\text { Error }\end{array}$ \\
\hline Foreign & $0.295^{* *}$ & 0.108 & $0.161 * *$ & 0.048 & $0.252 * *$ & 0.085 \\
\hline Domestic & $0.262 * *$ & 0.049 & $0.209 * *$ & 0.028 & $0.319 * *$ & 0.047 \\
\hline MEBO Partics. & $0.073 * *$ & 0.017 & $0.068 * *$ & 0.012 & 0.045 & 0.025 \\
\hline MPP Partics. & $0.132 * *$ & 0.034 & $0.108 * *$ & 0.024 & $0.126 * *$ & 0.043 \\
\hline POF & $0.081 *$ & 0.041 & $0.067 *$ & 0.032 & 0.009 & 0.056 \\
\hline Others & 0.089 & 0.078 & 0.108 & 0.056 & -0.026 & 0.126 \\
\hline $\mathrm{R}^{2}$ & \multicolumn{2}{|c|}{0.081} & \multicolumn{2}{|c|}{0.060} & \multicolumn{2}{|c|}{0.079} \\
\hline
\end{tabular}

Notes:

Number of observations: 14,532 .

$R^{2}$ : adjusted R-sq for OLS, pseudo R-sq for median regression, R-sq within for fixed effects regressions. Robust standard errors for OLS. Ownership variables: One year lagged values. All regressions include controls for previous performance, employment size and year effects. OLS and median regressions also include controls for region (6 categories) and industry (14 categories).

$* *=$ significant at 1 percent level

* = significant at 5 percent level 
Table 11: Impact of the Largest Owner-Type on the Level of Productivity

\begin{tabular}{|c|c|c|c|c|c|c|}
\hline \multirow[b]{3}{*}{$\begin{array}{l}\text { Largest Owner- } \\
\text { Type: }\end{array}$} & \multicolumn{6}{|c|}{ Dependent variable: Log Labor Productivity } \\
\hline & \multicolumn{2}{|c|}{ OLS } & \multicolumn{2}{|c|}{ Median } & \multicolumn{2}{|c|}{ Fixed effects } \\
\hline & Coeff. & $\begin{array}{l}\text { Std. } \\
\text { Error }\end{array}$ & Coeff. & $\begin{array}{l}\text { Std. } \\
\text { Error }\end{array}$ & Coeff. & $\begin{array}{l}\text { Std. } \\
\text { Error }\end{array}$ \\
\hline Foreign & $0.265 * *$ & 0.069 & $0.175 * *$ & 0.033 & $0.165^{* *}$ & 0.047 \\
\hline Domestic & $0.180 * *$ & 0.030 & $0.151 * *$ & 0.019 & $0.199 * *$ & 0.028 \\
\hline MEBO Partics. & $0.104 * *$ & 0.011 & $0.070 * *$ & 0.009 & $0.101 * *$ & 0.016 \\
\hline MPP Partics. & $0.073 * *$ & 0.017 & $0.053 * *$ & 0.013 & $0.084 * *$ & 0.019 \\
\hline POF & 0.144 & 0.092 & 0.070 & 0.095 & 0.227 & 0.137 \\
\hline Others & $0.291 * *$ & 0.088 & $0.173 * *$ & 0.058 & $0.337 * *$ & 0.083 \\
\hline $\mathrm{R}^{2}$ & \multicolumn{2}{|c|}{0.733} & \multicolumn{2}{|c|}{0.553} & \multicolumn{2}{|c|}{0.213} \\
\hline
\end{tabular}

Note:

Number of observations: 14,532 .

$R^{2}$ : adjusted R-sq for OLS, pseudo R-sq for median regression, R-sq within for fixed effects regressions. Ownership variables: One year lagged values. Robust standard errors for OLS.

All regressions include controls for previous performance, employment size and year effects. OLS and median regressions also include controls for region ( 6 categories) and industry (14 categories). ** = significant at 1 percent level

$*$ = significant at 5 percent level

Table 12: Impact of the Largest Owner-Type on Productivity Growth

\begin{tabular}{|c|c|c|c|c|c|c|}
\hline \multirow[b]{3}{*}{$\begin{array}{l}\text { Largest Owner- } \\
\text { Type: }\end{array}$} & \multicolumn{6}{|c|}{ Dependent variable: Change in Log Labor Productivity } \\
\hline & \multicolumn{2}{|c|}{ OLS } & \multicolumn{2}{|c|}{ Median } & \multicolumn{2}{|c|}{ Fixed effects } \\
\hline & Coeff. & $\begin{array}{l}\text { Std. } \\
\text { Error }\end{array}$ & Coeff. & $\begin{array}{l}\text { Std. } \\
\text { Error }\end{array}$ & Coeff. & $\begin{array}{l}\text { Std. } \\
\text { Error }\end{array}$ \\
\hline Foreign & $0.178 * *$ & 0.074 & $0.110 * *$ & 0.034 & $0.120^{*}$ & 0.056 \\
\hline Domestic & $0.141 * *$ & 0.031 & $0.116 * *$ & 0.020 & $0.159 * *$ & 0.033 \\
\hline MEBO Partics. & $0.047 * *$ & 0.011 & $0.038 * *$ & 0.009 & 0.032 & 0.019 \\
\hline MPP Partics. & $0.072 * *$ & 0.017 & $0.052 * *$ & 0.013 & $0.087 * *$ & 0.023 \\
\hline POF & 0.125 & 0.092 & 0.088 & 0.098 & 0.152 & 0.163 \\
\hline Others & $0.229 * *$ & 0.092 & $0.124 *$ & 0.060 & $0.209^{*}$ & 0.099 \\
\hline $\mathrm{R}^{2}$ & \multicolumn{2}{|c|}{0.079} & \multicolumn{2}{|c|}{0.059} & \multicolumn{2}{|c|}{0.077} \\
\hline \multicolumn{7}{|c|}{$\begin{array}{l}\text { Note: } \\
\text { Number of observations: } 14,532 \text {. } \\
R^{2}: \text { adjusted R-sq for OLS, pseudo R-sq for median regression, R-sq within for fixed effects } \\
\text { regressions. Ownership variables: One year lagged values. Robust standard errors for OLS. } \\
\text { All regressions include controls for previous performance, employment size and year effects. OLS } \\
\text { and median regressions also include controls for region ( } 6 \text { categories) and industry (14 categories). } \\
* *=\text { significant at } 1 \text { percent level } \\
*=\text { significant at } 5 \text { percent level }\end{array}$} \\
\hline
\end{tabular}


Table 13: Sources of the Data

\begin{tabular}{|c|c|c|}
\hline Database & Companies in the Database & Relevant Variables \\
\hline SOF Transactions & All sales that the SOF & Date of transaction \\
\hline \multirow[t]{5}{*}{ Database } & completed since the beginning & County \\
\hline & of its activity by $1999: \mathrm{I}$. & Percent of shares transacted \\
\hline & & Book value of the firm \\
\hline & & Method of privatization \\
\hline & & Type of buyer \\
\hline \multirow{8}{*}{$\begin{array}{l}\text { SOF Portfolio } \\
\text { Database }\end{array}$} & All companies that the SOF & County \\
\hline & ever had in its portfolio. & Industry code \\
\hline & & Percent owned by the SOF \\
\hline & & Percent sold by the POF by the end of the MPP \\
\hline & & Percent owned by the POF after the MPP \\
\hline & & Percent owned directly by managers \\
\hline & & Percent owned by "others" \\
\hline & & Percent distributed in the MPP \\
\hline POF Crisana-Banat & $\begin{array}{l}\text { Companies with POF holding } \\
\text { in December } 1998 .\end{array}$ & POF holding in December 1998 \\
\hline POF Moldova & $\begin{array}{l}\text { Companies with POF holding } \\
\text { in } 1997 \text { and } 1998 .\end{array}$ & POF holding in December 1997 and 1998 \\
\hline POF Muntenia & $\begin{array}{l}\text { Companies with POF holding } \\
\text { in } 1998 .\end{array}$ & POF holding in December 1998 \\
\hline POF Oltenia & $\begin{array}{l}\text { Companies with POF holding } \\
\text { in } 1998 .\end{array}$ & POF holding in December 1998 \\
\hline POF Transilvania & $\begin{array}{l}\text { Companies with POF holding } \\
\text { in } 1998 .\end{array}$ & POF holding in December 1998 \\
\hline Romanian & All registered enterprises with & County \\
\hline Enterprise Registry & at least 5 employees at the end & Industry \\
\hline 1992-1999 (one & of the given year. & Turnover \\
\hline $\begin{array}{l}\text { database for each } \\
\text { year) }\end{array}$ & & Number of employees \\
\hline
\end{tabular}

Note: firm ID included in all databases 
Table 14: Number of Firms with Non-Missing Employment and Turnover Data

\begin{tabular}{lllllllll}
\hline Year & 1992 & 1993 & 1994 & 1995 & 1996 & 1997 & 1998 & 1999 \\
\hline Number of firms & 1931 & 2074 & 2115 & 2134 & 2179 & 2183 & 2202 & 2168 \\
Percent of firms & 82.0 & 88.1 & 89.8 & 90.7 & 92.6 & 92.7 & 93.5 & 92.1 \\
\hline
\end{tabular}

Total number of firms: 2354

Table 15. Distribution of Firms by Industry

\begin{tabular}{lrr}
\hline & \multicolumn{2}{c}{ Percent of firms } \\
\hline Industry & $\begin{array}{c}\text { Number } \\
\text { of firms }\end{array}$ & $\begin{array}{r}\text { Percent } \\
\text { of firms }\end{array}$ \\
\hline Extraction, energy, water supply & 131 & 5.6 \\
Food & 509 & 21.6 \\
Textiles, clothing & 338 & 14.4 \\
Leather, footwear & 53 & 2.2 \\
Wood, paper & 108 & 4.6 \\
Polygraphy & 76 & 3.2 \\
Chemistry, plastics, rubber & 159 & 6.8 \\
Ceramics & 151 & 6.4 \\
Metallurgy & 69 & 2.9 \\
Metallic constructions & 186 & 7.9 \\
Machine building and transportation equip. & 300 & 12.7 \\
Electrical and optical equip. & 83 & 3.5 \\
Furniture and other unclassified & 146 & 6.2 \\
Recycling & 45 & 1.9 \\
\hline Total & $\mathbf{2 3 5 4}$ & $\mathbf{1 0 0 . 0}$ \\
\hline
\end{tabular}




\section{IZA Discussion Papers}

No Author(s)

241 W. Koeniger

242

G. Faggio

J. Konings

243

E. Brainerd

244 S. M. Fuess, Jr. M. Millea

245 F. Andersson

K. A. Konrad

246 E. Plug

W. Vijverberg

247 E. Plug

W. Vijverberg

248 P. M. Picard

E. Toulemonde

249

B. M. S. van Praag

P. Cardoso

250 T. J. Hatton

J. G. Williamson

251 R. Yemtsov

252 R. Yemtsov

253

R. Yemtsov

254 H. Gersbach

A. Schniewind

255

H. Gersbach

A. Schniewind
Titel

Area

Date

Trade, Labor Market Rigidities, and Government- 2

$01 / 01$ Financed Technological Change

Job Creation, Job Destruction and Employment 4

Growth in Transition Countries in the 90's

$01 / 01$

Economic Reform and Mortality in the Former

4

$01 / 01$

Soviet Union: A Study of the Suicide Epidemic in the 1990s

Pay and Productivity in a Corporatist Economy: $\quad 5$

$01 / 01$

Evidence from Austria

Globalization and Human Capital Formation

5

$01 / 01$

Schooling, Family Background, and Adoption:

5

Does Family Income Matter?

$01 / 01$

Schooling, Family Background, and Adoption:

5

$01 / 01$

Is it Nature or is it Nurture?

The Impact of Labor Markets on Emergence and 2

Persistence of Regional Asymmetries

"Should I Pay for You or for Myself?"

The Optimal Level and Composition of

Retirement Benefit Systems

Demographic and Economic Pressure on

Emigration out of Africa

Labor Markets, Inequality and Poverty in Georgia

$01 / 01$

Inequality and Income Distribution in Georgia

4

$01 / 01$

Living Standards and Economic Vulnerability in $\quad 4$

$01 / 01$

Turkey between 1987 and 1994

Learning of General Equilibrium Effects and the 3

Unemployment Trap

$02 / 01$

Product Market Reforms and Unemployment in 3

$02 / 01$ 
258 M. Rosholm

The Times They Are A-Changin':

02/01

K. Scott

Organizational Change and Immigrant 
273 G. Saint-Paul

274 P. J. Pedersen

N. Smith

275 G. S. Epstein

T. Lecker

276 B. Amable

D. Gatti

277 R. Winter-Ebmer

278 T. M. Andersen

279 T. M. Andersen

280 P. Apps

R. Rees

281

G. Saint-Paul

282

J. Albrecht

A. Björklund

S. Vroman

283 M. Hagedorn

A. Kaul

V. Reinthaler

284 H. Rapoport

A. Weiss

285

J. Jerger

C. Pohnke

A. Spermann

286 M. Fertig

C. M. Schmidt
Dynamic Self-Selection

Distribution and Growth in an Economy with

5

03/01

Limited Needs

Unemployment Traps: Do Financial Dis-

3

03/01

incentives Matter?

Multi-Generation Model of Immigrant Earnings: $\quad 1$

$03 / 01$

Theory and Application

The Impact of Product Market Competition on

5

$03 / 01$

Employment and Wages

Evaluating an Innovative Redundancy-Retraining 6 Project: The Austrian Steel Foundation

$03 / 01$

Welfare Policies, Labour Taxation and Inter-

2

$04 / 01$ national Integration

$04 / 01$

Product Market Integration, Wage Dispersion

2 and Unemployment

04/01

Household Savin
the Life Cycle

7

$04 / 01$

Information Technology and the Knowledge

5

04/01

Elites

Is There a Glass Ceiling in Sweden?

5

$04 / 01$

Welfare Analysis in a Schumpeterian Growth

7

$04 / 01$

Model with Capital

The Optimal Size for a Minority

$04 / 01$

Gut betreut in den Arbeitsmarkt?

5

04/01

Eine mikroökonometrische Evaluation der

Mannheimer Arbeitsvermittlungsagentur

First- and Second-Generation Migrants in Germany -What Do We Know and What Do People Think 
287 P. Guggenberger

A. Kaul

M. Kolmar

288

D. A. Cobb-Clark

289

L. Cameron

D. A. Cobb-Clark

290 D. A. Cobb-Clark

M. D. Connolly

C. Worswick

291 R. T. Riphahn

E. Wasmer

293

D. Cobb-Clark

T. F. Crossley

294 Š. Jurajda

295 F. Duffy

P. P. Walsh

296 H. S. Nielsen

M. Rosholm

N. Smith

L. Husted

297 J. C. van Ours

J. Veenman

298 P. Telhado Pereira

P. Silva Martins

G. Brunello

C. Lucifora

R. Winter-Ebmer

300 A. Stutzer

R. Lalive
Efficiency Properties of Labor Taxation in a

Getting Ahead: The Determinants of and Payoffs

5 to Internal Promotion for Young U.S. Men and Women

Old-Age Support in Developing Countries: Labor Supply, Intergenerational Transfers and Living Arrangements

The Job Search and Education Investments of

04/01 Immigrant Families

05/01

Cohort Effects in the Educational Attainment of Second Generation Immigrants in Germany: An Analysis of Census Data

Between-group Competition in the Labor Market and the Rising Returns to Skill: US and France 1964-2000

Gender, Comparative Advantage and Labor Market Activity in Immigrant Families Insurance Compensation on the Labor Market Histories of Displaced Workers

Individual Pay and Outside Options:

05/01

Evidence from the Polish Labour Force Survey

Intergenerational Transmissions and the School- 1 to-Work transition of $2^{\text {nd }}$ Generation Immigrants Immigrants in The Netherlands

Returns to Education and Wage Equations

06/01

The Wage Expectations of European College

5

06/01 Students

The Role of Social Work Norms in Job Searching 5 and Subjective Well-Being 

firm Bargaining

G. Abío

E. Berenguer

J. Gil

C. Patxot Accounting Perspective on Fiscal Policy and 
315 W. H. J. Hassink

R. Schettkat

316 M. Frondel

C. M. Schmidt

317 R. Winkelmann

318 M. Pannenberg

G. G. Wagner

319

R. Euwals

R. Winkelmann

320

R. Fahr

U. Sunde

321

P. Telhado Pereira

P. Silva Martins

O. Hübler

U. Jirjahn

323
A. Frederiksen
E. K. Graversen
N. Smith

324 M. Pflüger

325

R. A. Hart

J. R. Malley

U. Woitek

326
J. S. Earle
Á. Telegdy

On Price-Setting for Identical Products in Markets without Formal Trade Barriers

Rejecting Capital-Skill Complementarity at all

Costs

Health Care Reform and the Number of Doctor

7

Visits - An Econometric Analysis

06/01

Overtime Work, Overtime Compensation and the 1

06/01

Distribution of Economic Well-Being: Evidence for

West Germany and Great Britain

Why do Firms Train? Empirical Evidence on the

$06 / 01$

First Labour Market Outcomes of Graduated

Apprentices

Strategic Hiring Behavior in Empirical Matching 1

Functions

$06 / 01$

Is there a Return - Risk Link in Education?

5

07/01

Works Councils and Collective Bargaining in

1

07/01

Germany: The Impact on Productivity and Wages

Overtime Work, Dual Job Holding and Taxation

1

07/01

Trade, Technology and Labour Markets: Empirical 2

$07 / 01$ Controversies in the Light of the Jones Model

Real Wages and the Cycle: The View from the

1

$07 / 01$

Frequency Domain

Privatization and Productivity in Romanian

Industry: Evidence from a Comprehensive

4

$07 / 01$

Enterprise Panel 